\title{
SUSTAINABILITY REPORTING AND FINANCIAL PERFORMANCE OF LISTED CONSUMER GOODS FIRMS IN NIGERIA
}

\author{
Maryam Mohammed Umar ${ }^{1 *}$, Lateef Olumide Mustapha ${ }^{2}$, Onipe Adabenege Yahaya ${ }^{3}$ \\ ${ }^{* 1,2,3}$ Department of Accounting, Nigerian Defence Academy, Kaduna, Nigeria Corresponding author's email: \\ maryamm2mk@gmail.com
}

*Corresponding Author: -

Email:maryamm2mk@gmail.com

\begin{abstract}
: -
The non-compliance by firms on sustainable development gave rise to climate degradation and ozone layer depletion. The resultant consequences include pollution, habitat loss, and overexploitation of species and the spread of invasive genes. Yet, very few empirical studies have examined the effects of these on corporate performance. In view of this scenario, this study assesses the effects of sustainability reporting on financial performance of 26 listed consumer goods firms in Nigeria. Correlational research design was adopted for the study and secondary data were collected from the annual reports and accounts of the firms for a period of 10 years (2009-2018). Multiple regression technique used to analyse the data and diagnostic checks and post estimation tests were carried out on the data. The results show that social performance has significant positive effect on financial performance. Similarly, results show that environmental performance has significant positive effect on financial performance. However, results show that economic performance has a significant negative effect on financial performance. The study concludes that sustainability reporting is important to corporate financial performance. The study among others recommends that management should disclose more social and environmental performance activities and less economic performance activities.
\end{abstract}

Keywords: - economic performance; environmental performance, social performance. 


\section{INTRODUCTION}

Financial performance plays a significant role in increasing the market value of a firm. This is because shareholders are usually interested in the financial performance of firms in order to make wise investment and financial decisions that will maximize their wealth. It is interesting to note that assessing the determinants of financial performance has gained important momentum in the corporate finance literature because of the diversity and engagement of these firms in series of seemingly unrelated business activities that are prone to all sorts of risks (credit risk, market risk, foreign exchange risk, interest risk, financial risk and operating risk).

Financial performance which is the focus of this study measures the results of a firm's strategies, policies and operations in monetary terms. These results are reflected in firm's return on assets and return on equity. Thus, the financial performance of a firm has become of the major criteria in determining its success and is consistent with the desire to improve and increase probability of the firms so as to meet the goal of stakeholders (Gitman, 2017).

Sustainability reporting is a fairly recent phenomenon which has expanded over the last few years. Many firms now produce annual sustainability report and there are a wide array of ratings and standards used. While there are a variety of reasons that firms choose to produce sustainability report, the core reasons seem to be the twin coin of transparency and accountability. Often they also intended to improve internal processes, engage stakeholders and persuade investors (Bergman et al., 2010). Sustainability report is an organizational report that gives information about economic, environmental, social and governance activities of the firm. Sustainability reporting is not just report generated from collected data, instead it is a method to internalize and improve an organization's commitment to sustainable development in a way that can be demonstrated to both internal and external stakeholders.

While it is true that financial performance is influenced by a number of factors, the interest of this study is to examine the influence of sustainability performance indicators such as social performance indicators, economic performance indicators and environmental performance indicators on financial performance. It should be noted that this cause-andeffect relationship is not direct. In order words, it is arguable to say that when a firm discloses its responses to social, economic and environmental sustainability challenges, stakeholders will be excited and are willing to do more business with the firm, thereby increasing the likelihood of better or improved financial performance.

Consumer goods are large and multinational companies in nature that embark on various types of businesses. In Nigeria, this category of company is under the regulation of the Nigerian Stock Exchange (NSE). Consumer goods firms are companies producing consumable products like foods, beverages, alcoholic drinks, salts, foams, etc. Consumer goods firms are considered as important firms in Nigerian's economy because of the enormous varieties of goods produced for consumption of the citizen and its contribution to gross domestic product.

As long as the significance of consumer goods sector to the Nigerian's economy, connect with the importance of sustainability reporting to the performance of companies as identified in the finance literature, it is consistent to carry out a study on the effect of sustainability reporting on financial performance of listed consumer goods firms in Nigeria. This however, is to provide and improve empirical evidence in this area in line with the effort of improving the sector. It is against this background that this study examines the effect of sustainability reporting on financial performance of listed consumer goods firms in Nigeria.

The impact humans have on Earth has more than doubled over the last 45 years and is still growing as evidence shows that humans on an average are using 2.7 global hectares per capita, exceeding Earths estimated average bio-capacity of 2.1 global hectares per capita (Peattie \& Collins, 2009). Excessive and imprudent use of Earth's natural resources has been alleged to have contributed to climate change, pollution, habitat loss, overexploitation of species, and the spread of invasive species or genes. To control the impact humans are having on the Earth, the Living Planet Report WWF (2008) emphasized that immediate action needed to be taken to formulate and implement strategies that promote sustainable development. It is envisaged that a sustainable development initiative will minimize the use of natural resources and reduce emissions of waste and pollutants over the life cycle so that it does not jeopardize the needs of future generations (Ofstad, 1994). As corporations play an integral part in both intermediate and final production and consumption, it is postulated that sustainable production and consumption of resources by corporations would lead to an improvement in the environment and also reduce its associated side effects (Global Reporting Initiative, 2004).

A financial statement is prepared in the transparent way as it is a source which attracts the investor and create desire among them for making an investment in that company. Transparency in financial statements means that the statements should be user-friendly and clear, and everything should properly be disclosed. Sustainability issues can substantially damage the image of the company and thus affect its performance.

The objective of this study is to examine the effects of sustainability reporting on financial performance of listed consumer goods firms in Nigeria. In order to achieve this objective, the following hypotheses were formulated and tested:

HO1: Social performance has no significant effect on financial performance of listed consumer goods firms in Nigeria. $\mathrm{HO} 2$ : Economic performance has no significant effect on financial performance of listed consumer goods firms in Nigeria.

HO3: Environmental performance has no significant effect on financial performance of listed consumer goods firms in Nigeria.

It is instructive to note that this study is significant in several respects. Stakeholders such as environmental right groups, regulators, policy makers, researchers, management, sustainability advocates, economic policymakers, community and social organizations stand to benefit from the findings of the study. Also, the study contributes to the literature on 
concepts, empirics, models, methods and theories. The remaining parts of this study deal with conceptual, empirical and theoretical literature, methodology, results, discussion, conclusion and recommendations.

\section{Literature Review}

Elkington (2004) explains that sustainability reporting is a form of value reporting where an organization publicly communicates its economic, environmental and social performance to the public. A sustainability report provides a balanced and reasonable representation of the sustainability performance of the reporting organization, including both positive and negative contributions. However, these purposes consider neither the time dimension, nor the interactions among different sustainability dimensions (Lozano, 2011).

The economic dimension of sustainability concerns the impact of the organization on its stakeholders' economic conditions, and on local, national, and global economic systems. Financial performance is fundamental to an organization's understanding of its own sustainability. This detail is already usually recorded in financial accounts, however. What is often reported to be less, and is often desired by users of sustainability reports, is the contribution of an organization to the sustainability of a larger economic system.

The sustainability environmental dimension concerns the impacts an organization has on living and non-living natural systems, including ecosystems, land, air, and water. Environmental indicators cover both input performance (e.g., material, energy, water) and output performance (e.g., emissions, effluents, waste). They also cover performance related to biodiversity, compliance with the environment and other relevant information such as environmental expenditure and product and service impacts. Social performance indicators focus attention on the impact's organizations have on the local communities they operate in, and how they manage and mediate the risks that may arise from interactions with other social institutions. Information is particularly sought on the risks associated with corruption and corruption, undue influence in public policy making and monopoly practices.

Financial performance measures how well a firm uses its resources to make profit and it is important to stakeholders. These stakeholders include trade creditors, bond holders, investors, employees and management. Each group has its own interest in tracking the financial performance of a firm. Analysts learn about financial performance from published annual reports and accounts. The report is a required legal document that must be published by all public firms. The purpose of the report is to provide stakeholders with accurate and reliable financial statements that provide an overview of the firm's financial performance. Financial performance can be measured in several ways such as book value per share, earnings per share, return on assets, and dividend per share, return on equity (Lawal et al., 2018).

In terms of empirical studies, Krishna and Lucus (2010) examine the effect of sustainability reporting on financial performance of 17 listed firms in New Zealand Stock Exchange and 51 listed in the Australian Stock exchange from the period 2002 to 2009. Results indicate that sustainability reporting is statistically significant in explaining abnormal returns for the Australian companies. Burhan and Rahamanti (2012) examine the relationship between sustainability reporting and company performance using a sample of 32 companies listed on the Indonesian Stock Exchange during the period 2006-2009. The result shows that sustainability reporting influences company performance.

Similarly, Garg (2015) examines the impact of sustainability reporting on firm performance of 20 listed firms BSE GREENEX Index of Bombay Stock Exchange from 2008 to 2012. The results reveal that sustainability reporting impact performance negatively in short run while positively in the long run. Also, Kwaghfan (2015) interrogates the impact of sustainability reporting on corporate performance of 64 companies selected from 76 non-financial companies quoted on the Nigerian Stock Exchange over a period of 11 years (2002-2012). Findings show that sustainability reporting impacted positively on financial performance.

Nur et al. (2016) interrogates the effect of sustainability reporting on financial performance of 200 public listed companies in Bursa Malaysia for a period of 8 years (2006-2013). The regression results suggest that economic, social and environmental sustainability reporting are positively associated with financial performance. Nobanee and Nejla (2017) examine the impact of economic, environmental and social sustainability reporting on financial performance of UAE banks over a period of 11 years (2003-2013). They measure sustainability disclosure based on economic disclosure, environmental, energy disclosure and social disclosure and financial performance using ROE. The results reveal no effect. Nnamani et al. (2017) examine the effect of sustainability reporting on financial performance using a sample of 3 listed brewery firms in Nigeria over a period of 5 years (2010-2014). Ordinary linear regression was used to analyse the data. The study reveals that sustainability reporting has positive and significant effect on financial performance.

Akabom et al. (2018) investigate the effect of sustainability reporting on corporate performance of 3 quoted brewery firms in Nigeria for a period of five years (2012-2016). The result shows that economic performance disclosure, environmental performance disclosure and social performance disclosure have no significant effects on financial performance. Sroufe and Gopalakrishna-Remani (2018) conduct a study on the effect of social sustainability on corporate performance using a sample of Fortune 500 firms, the Corporate Knights Global 100 and the 100 Best Corporate Citizens lists. Results show positive relationship between sustainability practices and firm financial performance. Similarly, Johari and Komathy (2019) examine the impact of sustainability reporting on financial performance of publicly listed firms in Malaysia. Results show that sustainability reporting has a positive effect on firm performance.

One of the theories relevant to this study is the agency theory, which is based on principal- agent relationship. The agency theory has gained significance in the wake of corporate governance scandals such as Enron, Cadbury and WorldCom. It is well known that conflict of interest and information asymmetry exists between company managers (insiders) and shareholders and other stakeholders (outsiders). In the absence of adequate public disclosure, the amount of risk perceived 
by investors rises significantly (de Klerk \& de Villiers, 2012). This causes the market to undervalue the shares or demand more returns from firms. Sustainability reporting reduces information asymmetry and risk perceived by investors, increases market efficiency and reduces cost of capital to firm (Dhaliwal et al., 2011; Warren \& Thomsen, 2012). Since the study is an attempt to explain the actions of companies in terms of sustainability reporting and how these actions affect firm financial performance, it adopts the stakeholders' theory. In other words, this study is anchored on stakeholders' theory because companies ought to consider the effects of their actions on stakeholders, namely customers, employees, suppliers and general public who have stakes in the company after all the purpose of the enterprise is to generate revenue and distribute this revenue among stakeholders.

\section{Methodology}

Data for this study were sourced from the audited financial statements of the sampled listed consumer goods firms in Nigeria for a period of 10 years (2009-2018). The study adopted correlational research design. The population of this study consists of 26 listed consumer goods firms. This was obtained from Fact Book of Nigerian Stock Exchange as at December 2018. Census sampling techniques was applied and all the 26 listed consumer goods were taken as sample size. The panel data was analyzed using multiple regression analysis. The model used in the study is a modified form of Argyrous (2005) and Onwumere (2009). The model relates financial performance to sustainability reporting as follows:

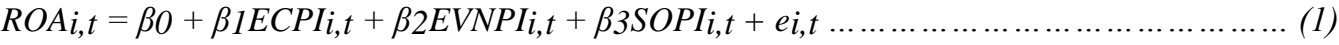

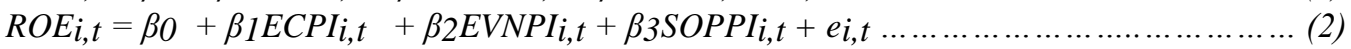

Whereas:

FP = Financial performance, measured by return on assets (ROA) and return on equity (ROE).

ROA = Return on assets, measured as profit before taxes/total assets (Ijaz \& Naqvi, 2016; Yahaya \& Lamidi, 2015).

$\mathrm{ROE}=$ Return on equity, measured as profit after taxes/equity (Nur et al., 2016; Yahaya \& Lamidi, 2015).

$\beta 0=$ Constant

ECPI = Economic Performance, measured as product of economic disclosure index and economic sustainability index (Hussain et al., 2016)

EVNPI = Environmental performance, measured as product of environmental disclosure index and environmental sustainability index (Hussain et al., 2016).

SOPI = Social performance, measured as product of social disclosure index and social sustainability index (Hussain et al., 2016).

$\mathrm{i}=$ Firm Script ( $\mathrm{i}=26$ firms); $\mathrm{t}=$ Firm Script $(\mathrm{t}=10$ years)

$\beta 1, \beta 2, \beta 3$ are parameters to be estimated

$\varepsilon=$ Idiosyncratic error term

\section{Results and Discussion}

This section presents the results from the analysis of data and their interpretation.

Table 1: Descriptive Statistics

\begin{tabular}{cccccc}
\hline Variable & Obs & Mean & Std. Dev. & Min & Max \\
\hline ROE & 260 & .854 & .842 & -.713 & 3.192 \\
ROA & 260 & 2.810 & 1.915 & .027 & 9.887 \\
SOPI & 260 & .930 & .411 & -1.270 & 1.919 \\
ECPI & 260 & 2.353 & 2.227 & -4.917 & 9.887 \\
ENPI & 260 & 1.616 & .886 & .012 & 4.878 \\
\hline
\end{tabular}

Source: STATA 13 Outputs

As shown in Table 1, the number of observations is 260, which is made up of 26 listed firms and 10 years covered by the study. The mean statistic value of ROE is 0.854 with standard deviation of 0.842 and minimum mean and maximum mean statistic values of -0.713 and 3.192, respectively. Similarly, the mean statistic of ROA is 2.81 with standard deviation of 1.915 and minimum mean and maximum mean statistic values of .027 and 9.887 , respectively. Also, the mean statistic of SOPI is 0.930 with standard deviation of 0.411 and minimum mean and maximum mean statistic values of 1.270 and 1.919, respectively. Similarly, the mean statistic of ECPI is 2.353 with standard deviation of 2.227 and minimum mean and maximum mean statistic values of -4.917 and 9.887 , respectively. Finally, the mean statistic of ENPI is 1.616 with standard deviation of 0.886 and minimum mean and maximum mean statistic values of 0.012 and 4.878 , respectively. These results indicate clearly and instructively that the mean statistic values of all the variables are higher than their standard deviation values suggesting that there is no volatility (dispersion) in the data set. The results of normality test are reported in Table 2 .

Table 2: Shapiro-Wilk W Test for Normal Data

\begin{tabular}{lccccc}
\hline Variable & Obs & W & V & Z & Prob $>$ Z \\
\hline ROE & 260 & 0.914 & 16.094 & 6.477 & 0.000 \\
ROA & 260 & 0.743 & 48.258 & 9.037 & 0.000 \\
SOPI & 260 & 0.927 & 13.623 & 6.088 & 0.000 \\
ECPI & 260 & 0.875 & 23.478 & 7.357 & 0.000 \\
ENPI & 260 & 0.913 & 16.317 & 6.509 & 0.000 \\
\hline
\end{tabular}


As shown in Table 2, the p-values of all the variables are significant, that is, they are less than 0.05 . These results indicate that the data set are not normally distributed and require that the heteroskedasticity test and regression analysis use robust standard errors instead of the normal standard errors. The results of multicollinearity test are reported in Table 3.

Table 3: Correlation Matrix

\begin{tabular}{lccc}
\hline Variable & SOPI & ECPI & ENPI \\
\hline SOPI & 1.000 & & \\
ECPI & -0.278 & 1.000 & \\
& 0.000 & & 1.000 \\
ENPI & 0.536 & -0.384 & \\
& 0.000 & 0.000 & \\
\hline
\end{tabular}

\section{Source: STATA 13 Outputs}

As shown in Table 3, none of the correlation value is up to 0.80 , which would have suggested the presence of heteroskedasticity among the independent variables. However, in order to verify these results, variance inflation factor was calculated for the data set. The results are reported in Table 4.

Table 4: Variance Inflation Factor (VIF)

\begin{tabular}{lll}
\hline Variable & VIF & $1 /$ VIF \\
\hline ENPI & 1.53 & 0.653 \\
SOPI & 1.43 & 0.707 \\
ECPI & 1.18 & 0.845 \\
Mean VIF & 1.38 & \\
\hline
\end{tabular}

Source: STATA 13 Outputs

As shown in Table 4, the VIF values of all the three independent variables are less than 4, which reaffirm the results in Table 3, which indicate that there is absence of multicollinearity among the independent variables. Also, the results of heteroskedasticity tests are reported in Table 5 for both ROE and ROA models using Cameroon and Triveldi imtest because of the failed normality test in the data set as shown in Table 2.

Table 5: Results of Heteroskedasticity Tests

\begin{tabular}{ccc}
\hline Model & ROE & ROA \\
\hline Chi2(1) & 107.65 & 43.90 \\
Prob $>$ Chi2 & 0.0000 & 0.0000 \\
\hline
\end{tabular}

Source: STATA $13 \overline{\text { Outputs }}$

As shown in Table 5, both models show evidence of heteroskedasticity with p-values less than 0.05 . Thus, there is need to robust the regression analysis using robust standard errors instead of the normal standard errors. Furthermore, the results of serial (auto) correlation are reported in Table 6.

Table 6: Results of Wooldridge Test for Autocorrelation in Panel Data

\begin{tabular}{ccc}
\hline Model & ROE & ROA \\
\hline $\mathrm{F}(1,25)$ & 12,310 & 4.094 \\
Prob $>$ F & 0.0017 & 0.0538 \\
\hline
\end{tabular}

Source: STATA 13 Outputs

As shown in Table 6, the p-value of ROE is significant, that is, there is presence of serial (auto) correlation in the model. However, the p-value of ROA is not significant, that is, there is no serial (auto) correlation in ROA model. Thus, both require different regression model to take into account the differences in the results of serial (auto) correlation tests. The ROE model therefore requires Newey-West regression analysis because of the presence of serial (auto) correlation, while the ROA model will use robust standard errors-based regression analysis. Also, the results of panel effect test are reported in Table 7.

Table 7: Results of Breusch and Pagan Lagrangian Multiplier Test for Random Effects

\begin{tabular}{ccc}
\hline Model & ROE & ROA \\
\hline Chibar2 (01) & 339.84 & 8.27 \\
Prob > chibar2 & 0.0000 & 0.0020 \\
\hline
\end{tabular}

Source: STATA 13 Outputs

As shown in Table 7, the p-values of ROE and ROA are both significant, that is, there is panel effects in the two models and thus require further tests to determine whether random or fixed effects are most appropriate for the regression analysis. Table 8 reports the results of the Hausman specification test. 
Table 8: Results of Hausman Specification Test

\begin{tabular}{ccc}
\hline Model & ROE & ROA \\
\hline Chi $^{2}(3)$ & 56.42 & 22.29 \\
Prob $>$ chi $^{2}$ & 0.0000 & 0.0001
\end{tabular}

Source: STATA $13 \overline{\text { Outputs }}$

As shown in Table 8, the p-values of ROE and ROA are both significant, that is, fixed effects model is most appropriate for the two models. In view of these results, the results of regression analysis in Table 9 are based on fixed effects model.

Table 9: Results of Regression Analysis

\begin{tabular}{lcccccc}
\hline Model & \multicolumn{3}{c}{ ROE } & \multicolumn{3}{c}{ ROA } \\
\hline Variable & Coef. & t-value & p-value & Coef. & t-value & p-value \\
SOPI & .274 & 2.26 & 0.025 & 1.478 & 2.93 & 0.007 \\
ECPI & -.089 & -5.07 & 0.000 & -.037 & -0.49 & 0.627 \\
ENPI & .520 & 7.09 & 0.000 & -.583 & -2.09 & 0.047 \\
cons & -.031 & -0.21 & 0.838 & 2.465 & 4.09 & 0.000 \\
F-stat & & 54.59 & & & 4.05 & 0.018 \\
Prob $>$ F & & 0.000 & & & 0.148 & \\
$\mathrm{R}^{2}$ & & 0.469 & & & & \\
\hline
\end{tabular}

Source: STATA 13 Outputs

As shown in Table 9, it is clear and instructive to note that ROE model is better than ROA model given the fact that it has higher F-stat, Prob > F and $\mathrm{R}^{2}$. Henceforth, the analysis of the results in Table 9 was based on the ROE model. The results in Table 9 indicate that SOPI has positive $(0.274)$ and significant (t-value $=2.26$; $\mathrm{p}$-value $=0.025$ ) effect on ROE. The coefficient suggests that for every additional disclosure of social performance item, financial performance improves by $0.274(27.4 \%)$. However, the results in Table 9 indicate that ECPI has negative (- 0.089) but significant (tvalue $=-5.07 ; \mathrm{p}$-value $=0.000$ ) effect on ROE. The coefficient suggests that for every item of economic performance disclosure, financial performance decreases by 0.089 (8.9\%). In addition, the results in Table 9 indicate that ENPI has positive $(0.520)$ and significant $(\mathrm{t}$-value $=7.09$; $\mathrm{p}$-value $=0.000)$ effect on ROE. The coefficient suggests that for every item of environmental performance disclosure, financial performance improves by 0.520 (52\%).

Also, the results in Table 9 indicate that the three proxies of sustainability reporting (social performance, economic performance and environmental performance) explain only about $46.9 \%$ of the variations in financial performance (ROE). This implies that further study is required to improve the predictive capacity of the model.

The results of ROE model in Table 9 are used to test the hypotheses of the study. As indicated in Table 9, SOPI shows positive and significant effect on ROE. Therefore, hypothesis one, which states that social performance has no significant effect on financial performance is hereby rejected since the results indicated otherwise. Similarly, hypothesis two, which states that economic performance has no significant effect on financial performance is hereby rejected since the results indicated otherwise. Finally, hypothesis three, which states that environmental performance has no significant effect on financial performance is hereby rejected since the results indicated otherwise. In the three hypotheses, the null hypotheses are hereby rejected while the alternate hypotheses are accepted.

In this section, the results of this study are compared and contrasted with results of empirical studies as reviewed in chapter two. The results indicate that SOPI has positive $(0.274)$ and significant (t-value $=2.26$; $\mathrm{p}$-value $=0.025)$ effect on ROE. The coefficient suggests that for every item of social performance disclosure, financial performance improves by $0.274(27.4 \%)$. However, the results in of economic performance indicate that ECPI has negative (-0.089) but significant ( $\mathrm{t}$-value $=-5.07$; $\mathrm{p}$-value $=0.000)$ effect on ROE. The coefficient suggests that for every item of economic performance disclosure, financial performance decreases by $0.089(8.9 \%)$. The result of environmental performance indicates that ENPI has positive $(0.520)$ and significant ( $\mathrm{t}$ - value $=7.09$; p-value $=0.000$ ) effect on ROE. The coefficient suggests that for every item of environmental performance disclosure, financial performance improves by $0.520(52 \%)$. This result is in line with the findings of Burhan and Rahamanti (2012) and Sroufe and GopalakrishnaRemani (2018).

\section{Conclusion and Recommendations}

This study examines the effects of sustainability reporting on financial performance of listed Consumer Goods firms in Nigeria for the period of ten (10) years 2009-2018. The study discovered that social performance of the listed consumer in Nigeria has significant effect on its return on Equity and significant positive effect on Return on Asset that served as measurement of financial performance in this study, Economic performance has a negative effect on Return on Equity as a measurement of financial performance while it was established that significant relationship between economic performance and Return on Equity as measurement of financial performance of listed consumer goods firms in Nigeria and Social performance has significant effect on both (Return on Asset and Return on Equity) as a measurement of financial performance of the listed consumer goods firms in Nigeria.

The study concludes that social dimension of sustainability concerns such as (labour practices, human rights and relationship with communities within which it operates) are very important in consideration of financial performance, 
the economic conditions of firms'stakeholders and the interaction or relationship with the economic systems at local, national, and global levels are important consideration for financial performance and the environmental dimension of sustainability (ecosystems, land, air, water, material, energy, emissions, effluents and waste are very important in consideration of financial performance.

The study recommends that, Management should disclose the social dimension of sustainability concerns the impacts the firm has on the social systems such as labor practices, human rights and relationship with communities within which it operates since such disclosure help to improve the financial performance of the firm, Management should reduce or completely avoid disclosing the firm's impact on the economic conditions of its stakeholders and the interaction or relationship with the economic systems at local, national, and global levels. This is because the result indicates a negative effect on financial performance and Management should disclose the firm's impact on living and non-living natural systems, including ecosystems, land, air, and water. Environmental indicators cover performance related to inputs (e.g., material, energy, water) and outputs (e.g., emissions, effluents, waste).

\section{References}

[1].Adegbaju, A. A., \& Olokoyo, F. O. (2008). Recapitalization and banks performance. African Economic and Business Review, 6(1),1-4.

[2].Aggarwal, P. (2013). Sustainability reporting and its impact on corporate financial performance: A leterature review. Indian Journal of Commerce and Management Studies, 4(3), 51-61.

[3].Agnew, D. J. (2019). Who determines sustainability. Journal of Fish Biology, 94(6), 952-957.

[4].Ameer, R., \& Othman, R. (2012). Sustainability practices and corporate financial performance: A study based on the top global corporations. Journal of Business Ethics, 108(1), 61-79.

[5].Anazonwu, H. O., Egbunike, F. C., \& Gunardi, A. (2018). Corporate board diversity and sustainability reporting: A study of selected listed manufacturin firms in Nigeria. Indian Journal of Sustainability Accouting and Management, 2(1), 65-78.

[6].Argyros, I. K. (2005). Newton methods. Nova Publishers.

[7].Asaolu, T. O., Agboola, A. A., Ayoola, T. J., \& Salawu, M. K. (2012). Sustainability reporting in the Nigerian oil and gas sector. COLERM Proceedings, 1(3), 61-84.

[8].Asuquo, A. I., Dada, E. T., \& Onyeogaziri, U. R. (2018). The effect of sustainability reporting on corporate performance of selected quoted brewery firms in Nigeria. International Journal of Business \& Law Research, $6(3), 1-10$.

[9].Bergman, D., Taheri, K., \& Henriksson, F. (2010). The role of sustainability reports in investment analysis. Journal of Marketing, 80(2), 59-79.

[10]. Brundtland, G. H. (1987). Our common future call for action on sustainability. Environmental Conservation, 14(4), 291-294.

[11]. Burhan, A. H. N., \& Rahmanti, W. (2012). The impact of sustainability reporting on company performance. Journal of Economics, Business, and Accountancy Ventura, 15(2), 257-272.

[12]. Chen, L. (2015). Sustainability and company performance: Evidence from the manufacturing industry. Linköping University Electronic Press.

[13]. Ching, H. Y., Gerab, F., \& Toste, T. H. (2017). The quality of sustainability reports and corporate financial performance: Evidence from Brazilian listed companies. SAGE Open, 7(2), 215- 244.

[14]. Chinweoke, N., Chukwudinma, C., \& Elizabeth, N. C. (2015). Impact of commercial banks'loans and advances to agriculture and manufacturing sectors on the economic growth of Nigeria. International Journal of Arts \& Sciences, 8(5), 29-44.

[15]. Development, W. C. (1987). Sustainability reporting. World Commission on Environment and Development.

[16]. Dhaliwal, D. S., Li, O. Z., Tsang, A., \& Yang, Y.G. (2011). Voluntary nonfinancial disclosure and the cost of equity capital: The initiation of corporate social responsibility reporting. The Accounting Review, 86(1), 59-100.

[17]. Elkington, J. (1998). Cannibals with forks: The triple bottom line of 21 st century business.

[18]. Gabriola Island. British Columbia, Canada: New Society, 2(3), 1-16.

[19]. Elkington, J. (2004). Enter the triple bottom line. The triple bottom line: Does it all add up, 11 (12), 1-16.

[20]. Finch, N. (2005). The motivations for adopting sustainability disclosure. Working Paper of the Macquarie, $20-35$.

[21]. Garg, P. (2015). Impact of sustainability reporting on firm performance of companies in India. Int J Mark Bus Comm, 4(3), 38-45.

[22]. Gitman, L. J., Michael, D., Joehnk, S. S., \& Roger, H. J. (2015). Fundamentals of investing.

[23]. Pearson Higher Education AU.

[24]. Gray, R., Owen, D., \& Adams, C. (1996). Accounting \& accountability: changes and challenges in corporate social and environmental reporting. Prentice Hall.

[25]. Hussain, N., Rigoni, U., \& Orij, R. P. (2018). Corporate governance and sustainability performance: Anaysis of triple bottom line performance. Journal of Business Ethics, 149(2), 411-432.

[26]. Initiative, G. R. (2019). Sustainability report. korea: Disponvel em [http://www. globalreporting. org]. Acessado em, 17, 01-09.

[27]. Johari, J. (2019). Sustainability reportin and firm performance: Evidence in Malaysia.

[28]. International Journal of Accounting, 4(17), 32-45.

[29]. Karlsson, J., \& Bäckström, S. L. (2015). Corporate sustainability and financial performance: The influence of board diversity in a Swedish context. DIVA Digitala Vitenkaplega Arkivet, 7(1), 58-70. 
[30]. Kasbun, N. F., Teh, B. H., \& SanOng, T. (2017). Sustainability reporting and financial performance of Malaysian public listed companies. Institutions and Economies, 2(4), 78-93.

[31]. King, M. E. (2006). The corporate citizen: Governance for all entities. Penguin Books, 17-18.

[32]. Kwaghfan, A. (2015). Impact of sustainability reporting on corporate performance of selected quoted companies in Nigeria. Journal of Accounting, 5(1), 65-93.

[33]. Lawal, O. D., Agbi, E. S., \& Mustapha, L. O. (2018). Effect of ownership structure on financial performance of listed insurance firms in Nigeria. Journal of Accounting, Finance and Auditing Studies, 4(3), 123-148.

[34]. Lin, W. C., Liu, C. F., \& Chu, C. W. (2005). Performance efficiency evaluation of the Taiwan's shipping industry: An application of data envelopment analysis. In Proceedings of the Eastern Asia Society for Transportation Studie, 5(2), 467-476.

[35]. Lindblom, C. K. (1994). The implications of organizational legitimacy for corporate social performance and disclosure. Critical Perspectives on Accounting Conference, New York 78.

[36]. Lizińska, J., \& Czapiewski, L. (2018). Towards economic corporate sustainability in reporting: What does earnings management around equity offerings mean for long-term Performance. Sustainability, 10(12), 4349.

[37]. Lozano, R. (2011). The state of sustainability reporting in universities. International Journal of Sustainability in Higher Education, 12(1), 67-78.

[38]. Marrewijk, M. V. (2003). Concepts and definitions of CSR and corporate sustainability between agency and communion. Journal of Business Ethics, 44, 95-105.

[39]. Michael, O. B., \& Badejo, S. O. (2014). Sustainable development reporting practices by Nigerian banks. Mediterranean Journal of Social Sciences, 5(23), 25-35.

[40]. Naz, F., Ijaz, F., \& Naqvi, F. (2016). Financial performance of firms: Evidence from Pakistan cement industry. Journal of Teaching and Education, 5(01), 81-94.

[41]. Nnamani, J. N., Onyekwelu, U. L., \& Ugwu, O. K. (2017). Effect of sustainability accounting and reporting on financial performance of firms in Nigeria brewery sector. European Journal of Business and Innovation Research, $5(1), 1-15$.

[42]. Nobanee, H., \& Ellili, N., (2017). Impact of economic, environmental, and social sustainability reporting on financial performance of UAE banks. Available at SSRN: https://ssrn.com/abstract=2971484 or http://dx.doi.org/10.2139/ssrn.2971484

[43]. Park, S. Y., \& Kohler, T. (2019). Collaboration for sustainable tourism through strategic bridging.

[44]. Journal of Vacation Marketing, 25(1), 99-110.

[45]. Patten, D. M. (1992). Intra-industry environmental disclosures in response to the Alaskan oil spill: A note on legitimacy theory. Accounting, Organizations \& Society, 17(5), 471-475.

[46]. Peattie, K., \& Collins, A. (2009). Guest editorial: Perspectives on sustainable consumption.

[47]. International Journal of Consumer Studies, 33, 107-112.

[48]. Rafuse, M. E. (1996). Working capital management: An urgent need to refocus. Management Decision, 34(2), 5963.

[49]. Reddy, K., \& Lucus, G. (2010). The effect of sustainability reporting on financial performance: An empirical study using listed companies. Journal of Asia Entrepreneurship and Sustainability, 6(2), 19-42.

[50]. Slater, A. (2008). KPMG International survey of corporate responsibility reporting. KPMG, Amsterdam, the Netherlands, 1(4), 70-79.

[51]. Sroufe, R., \& Gopalakrishna-Remani, V. (2018). Management, social sustainability, reputation, and financial performance relationships: An empirical examination of US firms. Organization \& Environment, SAGE Journals, $32(3), 10-86$.

[52]. Wagner, M. (2005). How to reconcile environmental and economic performance to improve corporate sustainability? Corporate environmental strategies in the European paper industry. Journal of Environmental Management, 76(2), 105-118.

[53]. Walley, N., \& Whitehead, B. (1994). It's not easy being green. Reader in Business and the Environment, 3(1), 3681.

[54]. Yahaya, O. A., \& Lamidi, Y. (2015). Empirical examination of the financial performance of Islamic banking in Nigeria: A case study approach. International Journal of Accounting Research, 42(2), 1-13. 